\title{
RANCANG BANGUN SISTEM E-VOTING PEMILIHAN KETUA OSIS SMA MARDISISWA SEMARANG BERBASIS WEB
}

\author{
Firman Setyawan $^{1 *}$, Fandy Indra Pratama ${ }^{2}$ \\ Jurusan TEKNIK INFORMATIKA, Fakultas TEKNIK, Universitas Wahid Hasyim \\ Jl. Menoreh Tengah X/22, Sampangan, Semarang 50236. \\ "Email: firman.setya90@unwahas.ac.id
}

\begin{abstract}
Abstrak
Dalam dunia pendidikan, teknologi informasi berperan sangat penting untuk menunjang proses belajar mengajar dan kegiatan penunjang yang ada di sekolah, namun belum semua proses kegiatan terakomodir oleh perkembangan teknologi. Sistem pemilihan ketua OSIS pada SMA Mardisiswa Semarang masih menggunakan cara konvensional. Proses voting yang dilakukan adalah secara centang atau coblos pada kertas suara menjadi cara dalam pemilihan calon ketua OSIS. Untuk mengatasi hal tersebut maka dibangun sebuah aplikasi untuk melaksanakan voting berbasis web atau yang disebut e-voting (electronic voting). Sistem evoting dianggap lebih efektif dan efisien mempermudah dalam proses perhitungan suara dan hasil pemilihan bisa langsung diketahui secara cepat dan akurat. Dalam proses pembuatan dan perancangan Sistem e-voting pemilihan ketua Osis pada SMA Mardisiswa berbasis web dibangun dengan menggunakan metode pengembangan sistem waterfall, bahasa pemrogaman PHP dan menggunakan database MySql. Sistem ini diharapkan agar siswa siswi dapat melakukan proses pemilihan Ketua Osis dengan mudah dan cepat mampu mengurangi permasalahan pada sistem pemilihan konvensional.
\end{abstract}

Kata Kunci : E-Voting, OSIS, PHP, Mysql

\section{PENDAHULUAN}

Dalam dunia pendidikan, teknologi informasi berperan sangat penting untuk menunjang proses belajar mengajar dan kegiatan yang ada di sekolah, namun belum semua proses kegiatan terakomodir oleh perkembangan teknologi. SMA Mardisiswa merupakan salah satu instansi pendidikan yang berada di Kecamatan Banyumanik, Semarang. Selama ini dalam pemilihan calon ketua OSIS baru masih menggunakan cara konvensional, yaitu voting secara langsung tidak memanfaatkan teknologi informasi. Proses voting yang dilakukan adalah secara centang atau coblos pada kertas suara menjadi cara dalam pemilihan calon ketua OSIS. Metode ini dinilai masih konvensional ditengah kemajuan teknologi dan informasi, memiliki kelemahan dari aspek efisiensi dan efektifitas. Persoalan pemungutuan suara yang boros secara anggaran dan rekapitulasi penghitungan suara dan waktu yang dibutuhkan dirasa tidak efisien. Hal ini dirasa kurang efektif dengan berkembangnya teknologi yang ada sekarang.

Sistem pemilihan ketua OSIS pada SMA Mardisiswa Semarang masih menggunakan cara konvensional, dimana siswa dan siswi harus menuju bilik suara, mencoblos atau mencontreng salah satu kandidat ketua OSIS serta panitia harus menghitung hasil dari kertas suara satu persatu. Sistem pemilihan konvensional memiliki beberapa kelemahan diantaranya memerlukan biaya lebih untuk penggunaan kertas, tinta, penyediaan bilik suara, lambatnya proses penghitungan suara dan terkadang kurang akuratnya hasil penghitungan suara, serta memerlukan waktu yang lebih lama. Untuk mengatasi hal tersebut maka dibangun sebuah aplikasi untuk melaksanakan voting berbasis web atau yang disebut $e$-voting (electronic voting). Diharapkan sistem ini dapat menggantikan sistem konvensional dan mampu memberikan hasil yang akurat, cepat dan efisien.

\subsection{Rumusan Masalah}

Berdasarkan uraian dari latar belakang diatas, maka penulis menyimpulkan Bagaimana membangun suatu sistem yang dapat membantu proses pemilihan ketua OSIS secara cepat dan efisien? 


\subsection{Tujuan Penelitian}

Tujuan penelitian ini adalah terciptanya suatu sistem $e$-voting pemilihan ketua OSIS berbasis web untuk mempermudah dan menggantikan sistem lama yang sudah ada agar lebih cepat dan efisien.

\subsection{Batasan Penelitian}

Agar pembahasan tidak menyimpang daru tujuan maka dibuat batasan masalah yaitu :

a. Pembangunan fitur yang terdapat pada sistem ini hanya dapat melihat, mengedit dan menghapus data.

b. Sistem ini bersifat lokal dan hanya dapat diakses dalam lingkup jaringan pada SMA Mardisiswa Semarang.

c. Sistem tidak merekomendasi diakses melalui smartphone atau handphone.

\section{TINJAUAN PUSTAKA}

Mengacu pada penelitian sebelumnya yaitu Perancangan E-voting Berbasis WEB (Studi Kasus Pemilihan Kepala Daerah Sukoharjo) (Nugroho, 2011). Penelitian tersebut mengenai aplikasi untuk melakukan voting kepala daerah Sukoharjo. Aplikasi yang dibangun menggunakan PHP dan MySQL sebagai database server. Dalam aplikasi voting tersebut, pemilih melakukan login dengan menggunakan nomor KTP yang dimilikinya.

Lestariningati (2009) dalam Seminar Nasional Informatika 2009 UPN "Veteran" Yogyakarta dengan judul "DESAIN SISTEM ONSITE VOTING UNTUK MENGATASI FRAUD" menyatakan bahwa dinegara-negara besar seperti Amerika dan Belanda telah menggunakan $e$-voting. Dengan teknologi $e$ voting dimungkinkan sistem voting untuk pemilihan umum dapat mengatasi berbagai masalah seperti penipuan, autentikasi atau keabsahan pemilih, security atau keamanan data, dan juga dapat mengakomodir terhadap keinginan untuk kecepatan dan ketepatan dalam penghitungan suara.

\subsection{Evoting}

Evoting adalah suatu sistem pemilihan dimana data dicatat, disimpan dan diproses dalam bentuk informasi digital. Dengan kata lain, e-voting merupakan pemungutan suara yang proses pelaksanaannya mulai dari pendaftaraan pemilih, pelaksanaan pemilihan, perhitungan suara dan pengiriman hasil suara dilaksanakan secara elektonik (digital)

(Rokhman, 2011).

\subsection{Use Case}

Use Case Diagram merupakan rangkaian tindakan yang dilakukan oleh sistem, aktor mewakili user atau sistem lain yang berinteraksi dengan sistem yang dimodelkan (Satzinger, 2011). Use case diagram adalah rangkaian / uraian sekelompok yang saling terkait dan membentuk sistem secara teratur yang dilakukan atau diawasi oleh sebuah aktor.

\subsection{Activity Diagram}

Diagram aktivitas tipe khusus dari diagram status yang meperlihatkan aliran dari suatu aktivitas ke aktivitas lainnya dalam suatu sistem. Diagram ini penting dalam suatu sistem serta pemodelan fungsi-fungsi suatu sistem dan memberi tekanan pada aliran kendali antar objek. (Muslihudin, 2016).

\subsection{Metode Waterfall}

Untuk metode pengembangan sistem yang baik dan berkualitas, salah satu metode yang digunakan adalah metode daur hidup rekayasa perangkat lunak yang dikenal adalah metode air terjun (waterfall). Model ini disebut juga linear sequential. Metode waterfall merupakan model pengembangan sistem informasi yang sistematik dan sekuensial. Metode Waterfall memiliki tahapan-tahapan sebagai berikut :

1) Requirements analysis and definition. Layanan sistem, kendala, dan tujuan ditetapkan oleh hasil konsultasi dengan pengguna yang kemudian didefinisikan secara rinci dan berfungsi sebagai spesifikasi sistem.

2) System and software design. Tahapan perancangan sistem mengalokasikan kebutuhan-kebutuhan sistem baik perangkat keras maupun perangkat lunak dengan membentuk arsitektur sistem secara keseluruhan. Perancangan perangkat lunak melibatkan identifikasi dan penggambaran abstraksi system dasar perangkat lunak dan hubungannya.

3) Implementation and unit testing. Pada tahap ini, perancangan perangkat lunak direalisasikan sebagai serangkaian program atau unit program. Pengujian melibatkan verifikasi bahwa setiap unit memenuhi spesifikasinya. 
4) Integration and system testing. Unit-unit individu program atau program digabung dan diuji sebagai sebuah sistem lengkap untuk memastikan apakah sesuai dengan kebutuhan perangkat lunak atau tidak. Setelah pengujian, perangkat lunak dapat dikirimkan ke customer.

5) Operation and maintenance. Tahapan ini merupakan tahapan yang paling panjang. Sistem dipasang dan digunakan secara nyata. Maintenance melibatkan pembetulan kesalahan yang tidak ditemukan pada tahapan-tahapan sebelumnya, meningkatkan implementasi dari unit sistem, dan meningkatkan layanan sistem sebagai kebutuhan baru. (Sasmito, G. W. 2017).

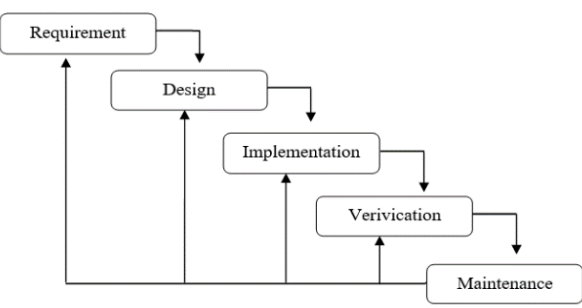

Gambar 1. Metode Waterfall

\section{ANALISIS DAN ALTERNATIF SISTEM}

Analisis terhadap sistem yang berjalan merupakan salah satu langkah untuk menentukan prosedur yang sedang dirancang, analisis sistem merupakan tahapan penelitian terhadap sistem berjalan (analisis system berjalan) yang dilakukan sebelum dibuatnya sebuah proses perancangan sistem dengan bertujuan untuk mengetahui permasalahan yang terjadi.

Tujuan analisis sistem yaitu mengkoreksi sistem apakah sudah berjalan dengan prosedur yang diinginkan atau masih ada kendala dalam pengaplikasiannya. Sistem yang bejalan saat ini di SMA Mardisiswa masih menggunakan cara konvensional atau manual dimana ini merupakan cara lama yang sudah tidak efektif. Prosedur pemilihan ketua Osis yang dilakukan saat ini adalah siswa dan siswi harus menuju bilik suara, mencoblos atau mencontreng salah satu kandidat ketua Osis serta panitia harus menghitung hasil dari kertas suara satu persatu.

\subsection{Identifikasi Masalah Pada Sistem Yang Berjalan}

Identifikasi masalah merupakan suatu awal sebelum menentukan rumusan masalah dalam suatu penelitian. Identifikasi masalah adalah tahap dimana objek dalam suatu jalinan tertentu bisa kita kenali sebagai suatu masalah. Berdasarkan analisis sistem yang telah dilakukan, dalam pemilihan Ketua Osis SMA Mardisiswa yang ada sekarang masih memiliki beberapa kelemahan diantaranya memerlukan biaya lebih untuk penggunaan kertas, tinta, penyediaan bilik suara, Terdapat surat suara tidak sah, dikarenakan kesalahan dalam proses pemilihan. lambatnya proses penghitungan suara dan terkadang kurang akuratnya hasil penghitungan suara, serta memerlukan waktu yang lebih lama.

\subsection{Alternatif Pemecahan Masalah}

Penulis telah merumuskan masalah yang dapat disimpulkan Pada tahap analisis sistem, sebuah cara yang dirancang oleh penulis, yang terdiri dari beberapa bagian yang merupakan implementasi dari fungsi - fungsi penting. Secara garis besar, sistem difungsikan sebagai berikut :

a. Sistem harus mampu melakukan verifikasi data pemilih yaitu siswa dan mengetahui status siswa, apakah siswa telah melakukan voting atau belum.

b. Siswa dapat memasukkan suara pilihannya ke dalam sistem.

c. Sistem harus dapat menjumlahkan hasil voting, dan menampilkannya.

\subsection{Perancangan}

Tahap desain merupakan tahap penjelasan kebutuhan yang telah direncanakan menjadi bentuk representasi dari sistem yang akan dibuat, dengan merancang Flowchart, Use Case Diagram, implementasi User Interface.

\subsubsection{Flowchart}

Flowchart seperti artinya yaitu diagram alur merupakan gambaran alur kerja dari sebuah sistem yang direpresentasikan melalui simbol tertentu. Dalam sistem evoting pemilihan Ketua Osis ini ini alur kerja dimulai dari admin yang membuat data calon kandidat Ketua Osis dan melakukan pembuatan data pemilih. Kemudian pemilih akan diberi kesempatan satu kali login untuk melakukan proses pemilihan. Setelah satu persatu pemilih telah melakukan pemilihan maka data hasil suara pemilihan akan diproses oleh admin dan diumumkan.

a. Flowchart pemilihan atau input suara kandidat 


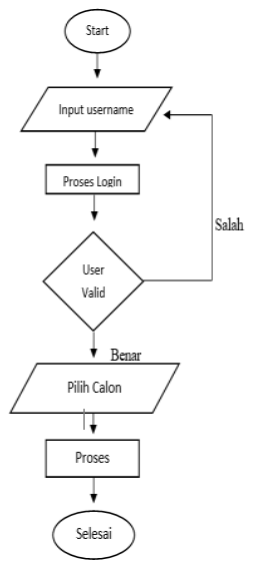

Gambar 2. Flowchart Pemilihan

b. Flowchart tambah pemilih

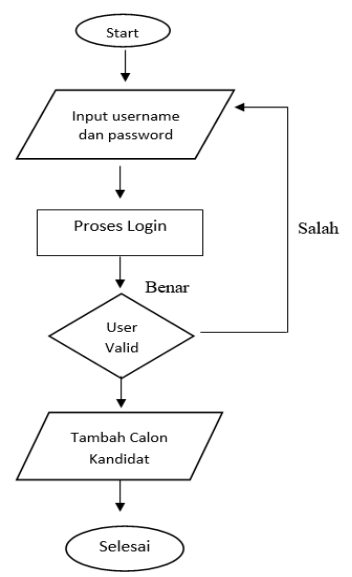

Gambar 3. Flowchart tambah pemilih

c. Flowchart laporan hasil suara

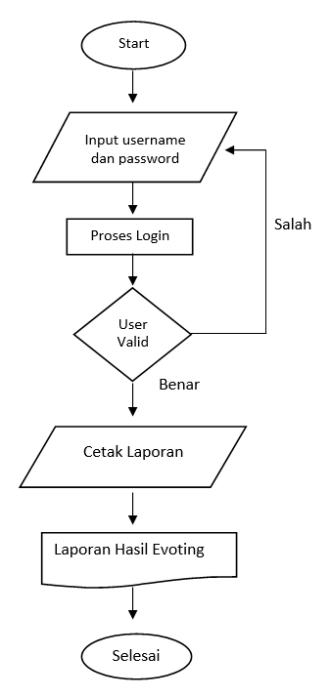

Gambar 4. Flowchart laporan hasil suara

\subsubsection{Use case}

Dalam Use case Diagram ini terdapat 2 aktor yaitu Admin dan Pemilih. Admin memiliki akses untuk melakukan pengelolaan sistem seperti menambah, mengedit calon kandidat dan data pemilih kemudian melihat laporan. Pada bagian pemilih hanya dapat melakukan fungsi pilih dan melihat visi misi calon kandidat

a. Use case admin

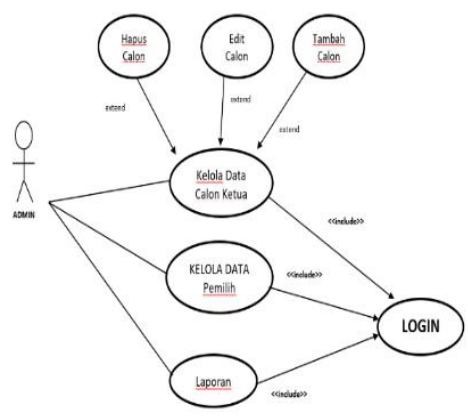

Gambar 5. Use case admin

b. Use case pemilih

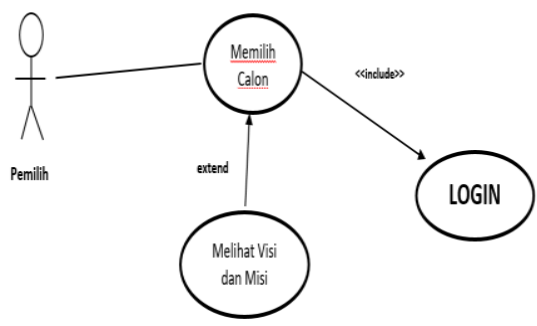

Gambar 6. Use case pemilih

\subsubsection{Activity Diagram}

Activity Diagram, menggambarkan tentang aktifitas yang terjadi dalam sistem. Dari pertama sampai akhir, diagram ini menunjukkan langkah-langkah dalam proses kerja sistem yang kita buat. 
a. Activity Diagram Pemilihan

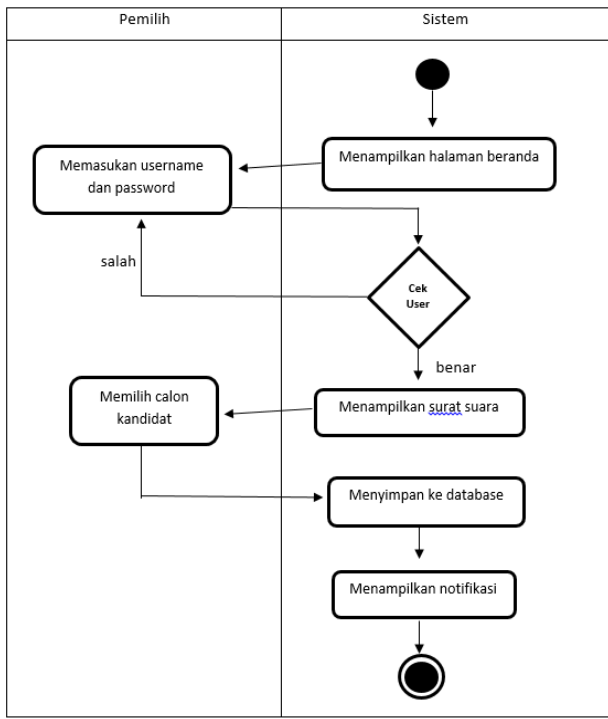

Gambar 7. Activity diagram pemilihan

b. Activity Diagram Tambah Pemilih

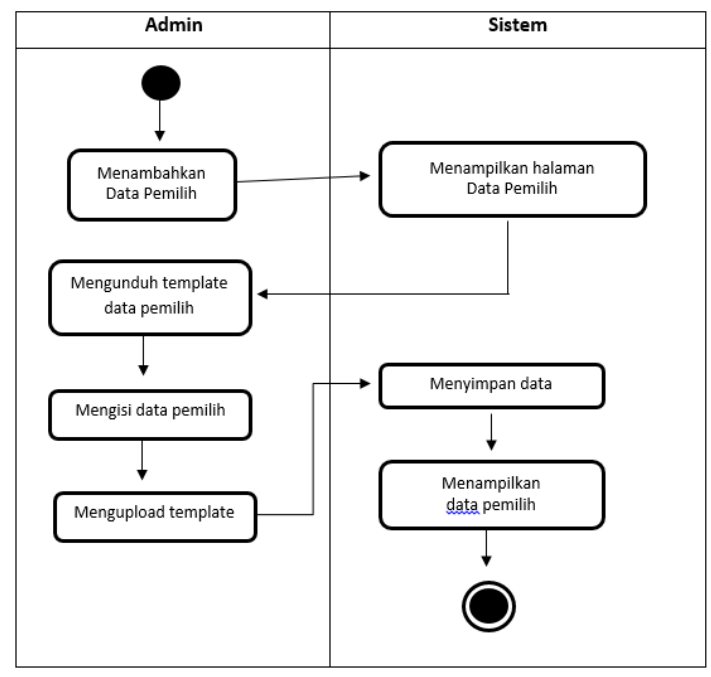

Gambar 8. Activity diagram Tambah Pemilih

c. Activity Diagram Laporan Hasil Perolehan Suara

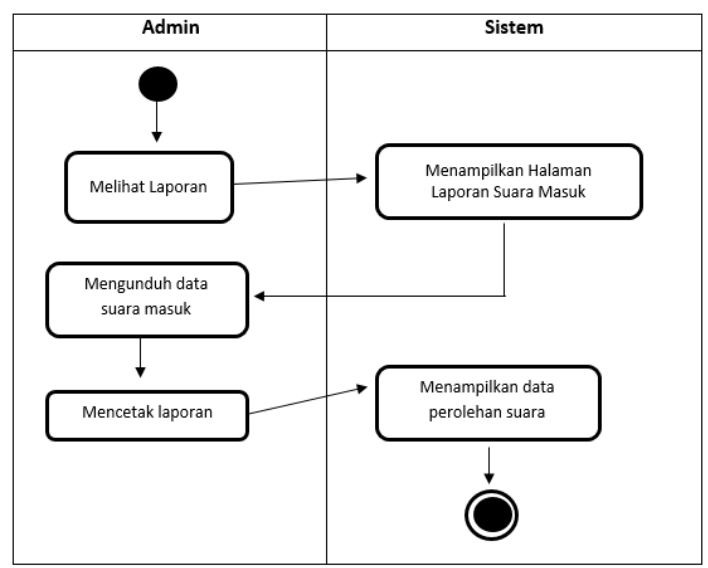

Gambar 9. Activity diagram pemilihan

\subsection{Desain Sistem \\ 3.4.1 Halaman Login}

Halaman login merupakan halaman awal ketika ingin mengakses masuk sebuah sistem sebagai admin pengelola sistem. Pengguna diharapkan memasukan username dan password. Kemudian sistem akan memvalidasi apakah sudah benar, jika benar maka akan lanjut ke halaman beranda atau halaman utama,

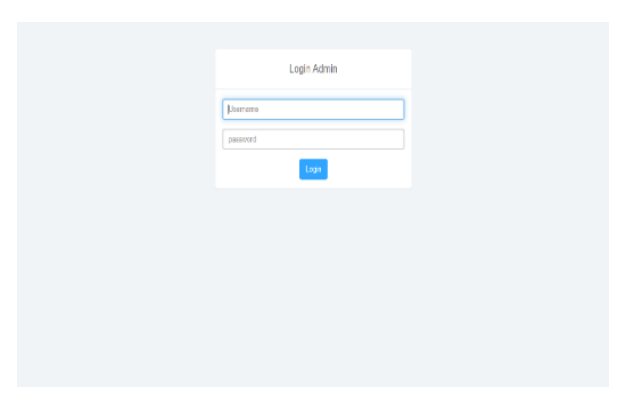

Gambar 10. Halaman login

\subsubsection{Halaman Beranda}

Halaman utama atau halaman beranda merupakan tampilan pertama yang akan tampil ketika seorang admin berhasil login setelah dilakukan verivikasi oleh sistem. Di dalam halam utama ini terdapat fungsi - fungsi penunjang dari sistem evoting ini antara lain pengelolaan input calon ketua atau kandidat, pengolalaan data pemilih dan laporan hasil suara pemilihan 


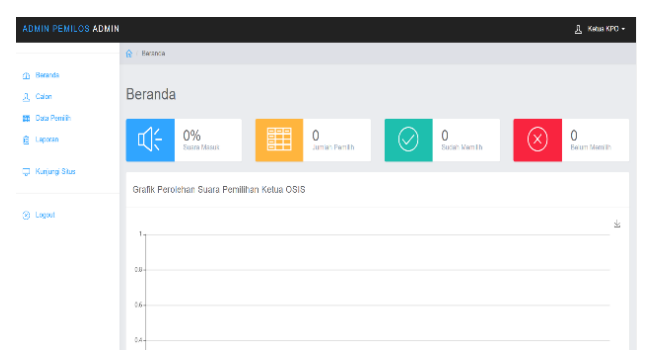

Gambar 11. Halaman Beranda

\subsubsection{Halaman Tambah Data Pemilih}

Pada halaman data pemilih, penulis atau pembuat sistem menggunakan fungsi import data. Dengan fungsi import data maka akan memudahkan admin dalam mengisi atau membuat data pemilih lebih cepat yaitu menggunakan template berupa file excel kemudian diunggah ke dalam sistem. Di halaman ini juga terdapat keterangan, yaitu pemilih sudah melakukan pemilihan atau belum

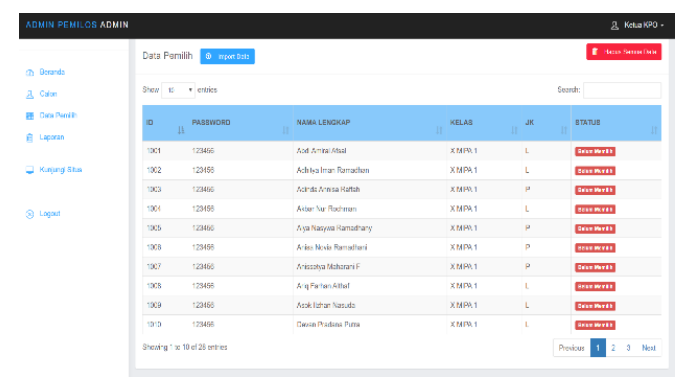

Gambar 12. Halaman tambah data pemilih

\subsubsection{Halaman Hasil Perolehan Suara}

Pada halaman ini admin dapat melihat hasil perolehan suara pemilihan semua calon kandidat. Penulis juga menambahkan fungsi cetak

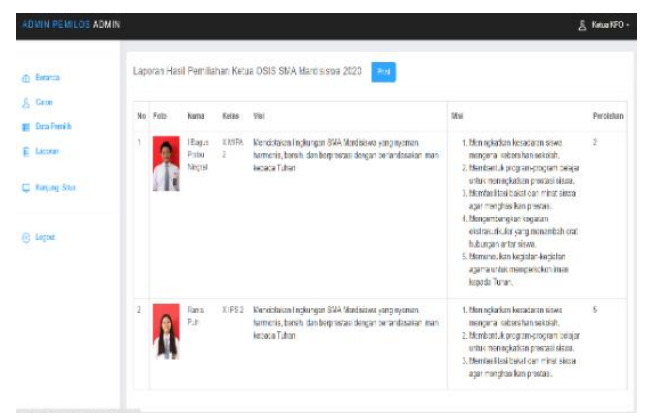

Gambar 13. Halaman hasil perolehan suara

\subsubsection{Halaman Login Pemilihan}

Halaman utama pemilih merupakan tampilan awal dari halaman yang akan digunakan untuk login sebagai pemilih. Pada halaman ini berisi informasi singkat tentang tata cara pemilihan bagaimana pemilih memberikan suara atau pilihannya kepada calon kandidat Ketua Osis. Pemilih diwajibkan mengisi username dan password yang sebelumnya sudah dibuatkan dari admin untuk bisa masuk dan melakukan pemilihan melalui sistem

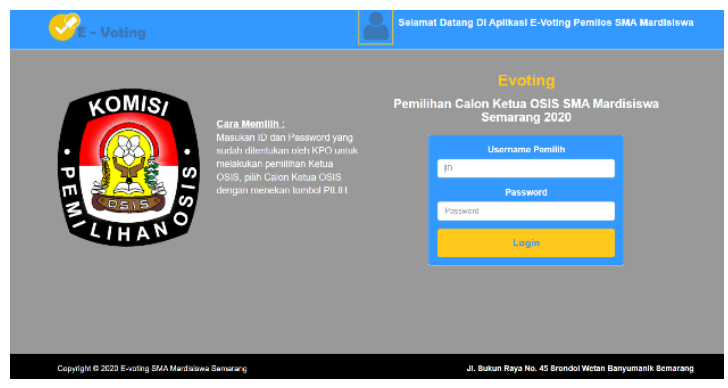

Gambar 14. Halaman login pemilihan

\subsubsection{Halaman Pemilihan}

Halaman pemilihan, merupakan halaman utama surat suara dan salah satu halaman yang penting yaitu melalui fungsi halaman ini lah seorang pemilih dapat memberikan suara pilihan kepada calon kandidat Ketua Osis. Pada tampilan halaman ini berisi foto calon kandidat dan fungsi lihat visi dan misi calon kandidat. Fungsi utama dari halaman ini adalah masukan atau inputan suara yang dipilih oleh pemilih kemudian data tersebut akan dikumpulkan dan bersumber di database sistem.

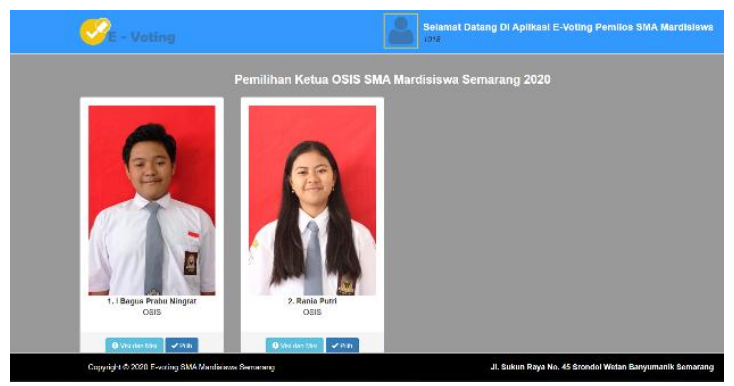

Gambar 15. Halaman pemilihan

\section{KESIMPULAN DAN SARAN}

\subsection{Kesimpulan}

Berdasarkan hasil penelitian, pengamatan dan perancangan sistem yang telah dibuat, berdasarkan permasalahan yang telah dikemukakan, dapat ditarik kesimpulan bahwa dengan adanya Sistem Evoting Pemilihan Ketua OSIS penulis mengambil kesimpulan sebagai berikut : 
1. Diharapkan siswa siswi dapat melakukan proses pemilihan Ketua Osis dengan mudah dan cepat. Menggunakan bagian teknologi sistem informasi dan demokrasi, tanpa mengurangi unsur pemilihan demokrasi yang sudah ada.

2. Aplikasi mampu menghasilkan sistem pengolahan hasil perolehan suara dengan akurat, cepat dan efisien

Sistem Evoting yang dirancang ini dapat mengurangi kelemahan dalam permasalahan sistem pemilihan manual antara lain hemat biaya dan mengurangi dan menimbulkan suara tidak sah.

\subsection{Saran}

Beberapa saran yang diberikan setelah dilakukan penelitian ini untuk pengembangan lebih lanjut adalah sebagai berikut :

1. Aplikasi sistem dapat ditambahkan dalam hal keamanan data.

2. Aplikasi dapat dikembangkan dalam bentuk aplikasi mobile smartphone untuk mempermudah perekaman suara / voting.

3. Perbaikan pada tampilan yang menarik agar mudah dalam penggunaan.

\section{DAFTAR PUSTAKA}

Lestariningati, S. I. (2015). Desain Sistem OnSite Voting Untuk Mengatasi Fraud. In Seminar Nasional Informatika (SEMNASIF) (Vol. 1, No. 6).

Muslihudin, M. (2016). Analisis Dan Perancangan Sistem Informasi Menggunakan Model Terstruktur Dan $U M L$. Penerbit Andi.

Nugroho, A.W. (2011). Perancangan e-Voting berbasis Web (Studi Kasus Pemilihan Kepala Daerah Sukoharjo). Internet: http://digilib. uin-suka. ac. id.

Rokhman, A. (2011). Prospek dan tantangan penerapan e-voting di indonesia. In Seminar Nasional Peran Negara dan masyarakat dalam Pembangunan Demokrasi dan Masyarakat madani di indonesia (Vol. 7, pp. 1-11).

Sasmito, G. W. (2017). Penerapan Metode Waterfall Pada Desain Sistem Informasi Geografis Industri Kabupaten Tegal. Jurnal Informatika: Jurnal Pengembangan IT, 2(1), 6-12.
Satzinger, J. W., Jackson, R. B., \& Burd, S. D. (2011). Systems analysis and design in a changing world. Cengage learning. 